Vol. 2 No. 2 Desember 2019, hal 212 - 227

\title{
SUPERVISING TEACHERS' INSIGHT IN DEVELOPING MOTIVATION AND CONFIDENCE OF PRE-SERVICE ENGLISH TEACHERS DURING TEACHING PRACTICUM
}

\author{
Indrawati ${ }^{1}$, Anna Musyarofah ${ }^{2}$ \\ 1,2IAIN Syaikh Abdurrahman Siddik Bangka Belitung \\ indrawati.fr@gmail.com
}

\begin{abstract}
Pre-Service English Teachers (PSTs) of Tarbiyah Fakulty of IAIN Syaikh Abdurrahman Siddik Bangka Belitung do their teaching practicum at high schools. Their supervising teachers play important role in evaluating, couching and mentoring them. In order to develop PSTs motivation and confidence during teaching and learning process, this study was conducted. Some supervising teachers from some high schools in Bangka regency and Pangkalpinang were interviewed. And the findings showed that PSTs should learn more about lesson planning, classroom management, and speaking skills. The result of the interviewed also gave a brief explanation about some subjects and courses that must be equipped by PSTs before they have their teaching practicum at schools.
\end{abstract}

Keyword : Pre-Service English Teachers, motivation, Practicum

\section{BACKGROUND}

As stated in Tadris Bahasa Inggris Curriculum of IAIN Syaikh Abdurrahman Siddik Bangka Belitung, that in the seventh semester of their study, every student must join Teaching practicum for two months. Teaching practicum is one of the most important parts of the students' learning experience in campus since it is a venue where they can challenge their competence and performance of teaching using English a medium of instruction(Richards, 2001). This PreService English Teachers (PST) should teach in senior high schools or junior high schools. Before they do their teaching practicum, they have been equipped with some courses namely; Curriculum Development in Language Teaching, Instructional Design, Teaching and Evaluation, TEFL Methodology, and Micro Teaching. Seeing those course names, we can easily manage to say that they 
should be good in teaching practicum in school, in a real classroom setting. But unfortunately, in reality, only some are good, and some are very disappointing.

In the seventh semester, Tadris Bahasa Inggris students of IAIN Syaikh Abdurrahman Siddik have their real teaching practice in high schools. Before conducting the teaching practice itself they should have done their micro teaching and peer teaching (PPLKI) at campus to prepare them to real teaching. And they also must finish some prerequisite subjects or courses like Curriculum Development in Language Teaching, Instructional Design, Evaluation, and Teaching Media and so on. This teaching practice or PPLK lasts for two months.

Teaching practice is an important stage for pre-service teachers who are currently still in college (Cohen, 2010) . This program provides opportunities for pre-service teacher students to get to know the real of teacher training before they actually enter it (Kabilan, 2013). PPLK teaches pre-service teachers how to master the four main competencies as a professional teacher. The first is pedagogic competence, namely the ability of teachers to combine the principles of teaching science with the abilities and backgrounds of their students. The second is personality competence, which is namely the ability of the teacher to be a role model for his students. Third, professional competence is the ability of the teacher to use the most effective techniques to involve students both inside and outside the classroom. And fourth, social competence which is the ability of teachers to identify environmental aspects that can improve the effectiveness of classroom learning.

Teaching practice is the practice of teaching in the real classroom (Fathurrahman \& Farih, 2019) which includes the application of a variety of main skills of a pre-service teacher such as: compiling a complete and correct lesson plan, applying classroom management skills, applying the skills to develop learning units, to start the lessons, applying the skills to carry out pre test, to present lessons, to motivate the students, to answer students' questions, applying skills to develop students' interest and attention, to use teaching aids / media, to use methods, approach or teaching techniques, applying skills to 
conclude lessons, to analyze test results, and applying the skills to close the lesson (Gan, 2013).

The success of the teaching practice is influenced by many factors. One of the factors is the existence of supervising teachers (Armutcu \& Yaman, 2010) (guru pamong). Supervising teachers is a teacher who is assigned to assist the pre-service teachers during PPLK in the training school. Supervising teachers is usually a class teacher who teaches the subject which is practiced by the PSTs (PST). This supervising teacher is assigned to guide the student in accordance with the field of study. In other words, we can say that the supervising teacher is a teacher of a particular subject who has the task of accompanying and guiding practicing PPLK students in conducting teaching practice at school. This supervising teacher is also assign to evaluate or to assess the PST during PPLK using instruments or certain formats which has been provided.

To conclude, the supervising teachers monitor, supervise, assess and evaluate the PSTs in teaching practice. This is the reason why the research problems of this study focused on the evaluation and suggestions from the supervising teachers during PPLK is taken into account. Since the supervising teachers monitor and evaluate the student's skills, competencies and performances during the teaching practice, their critics and evaluation in order to develop, improve and increase the students' ability in using English in their teaching will be investigated and revealed in this research.

\section{Supervising Teachers Role in Guiding the Student during Teaching Practice}

Supervising teacher is the teacher in charge of assisting the students during teaching practicum at schools. Supervising teachers usually a class teacher who teaches the field of study occupied by the PSTs. Supervising teachers have an important role in the success of PST in implementing their teaching practicum, , here are the supervising teacher's duties (Fairbanks, Freedman, \& Kahn, 2000):

1. Help the PSTs get to know the school's situation in general and provide orientation around the teaching program in the field of study he provides. 
2. Give an explanation to the PSTs about the possible activities that can be done in the school.

3. Guide the PSTs to compile the teaching practicum program.

4. Help the PSTs to provide the facilities and infrastructure needed in teaching practicum.

5. Organize teaching models to be observed by PSTs.

6. Giving assignments/teaching materials to the PSTs and guiding them to make the design of learning and the development of teaching materials.

7. Check the design of learning that has been compiled by the PSTs before the lesson is presented and the members input for improvement.

8. Monitor, supervise, and evaluate PSTs when teaching the practice.

9. Provide guidance on the implementation of teaching that has just been done by the PSTs and giving an assessment.

10. Guide the PSTs to draw as much experience as possible from school.

11. Monitor attendance, activeness of the PSTs in carrying out all the programmed PPL activities and examine and provide the endorsement in the personal books of each PST.

12. Assess the practical activities during teaching practicum using the instruments/formats provided.

13. Submit a list of PPL scores and all related instruments to the supervisor at the end of teaching practicum.

14. Check the final report prepared by PSTs; provide suggestions for improvement and endorsement.

\section{Motivation in Language Learning}

There have been many studies that discuss the problem of motivation. One of them is what Schmidt, Boraie and Kassabgy (Schmidt, Boraie, \& Kassabgy, 1996), (Inbar, Donitsa-Schmidt, \& Shohamy, 2001) have done. According to them motivation affects the learning methods that students choose or like. Students, who are instrumentally motivated, for example learning English only to face exams, will prefer traditional classes, where the class focuses on grammar lessons, and the teacher is the center of learning (teacher-centered). 
While students who are integrally motivated will prefer communicative classes, and are not interested in classes that focus on grammar lessons.

Schmidt, Boraie, and Kassabgy also found that students who had a goal in English, high expectations for success, and high strength showed that they were active students. They preferred classes in which there was a balance between the four skills language and balance between teacher and student control as a learning center. They also prefer challenging activities. Meanwhile, students who have high anxiety will not play an active role in class and they do not like activities that force them to play an active role in class because they prefer to remain silent in class.

The word 'motivation' is used in various senses. In general, motivation refers to a process that encourages a person to do something. Motivation is also often interpreted to mean choosing an activity or condition from a variety of selected activities. A longer understanding is stated by $\mathrm{O}$ 'Connor. He stated that motivation includes several important things (Segerstrom \& O'Connor, 2012). First, motivation is in a person. Motivation (as well as learning) cannot be directly examined. What can be investigated is the behavior caused by that motivation, and from here we can find out whether someone is 'motivated' or not.

Second, motivation persists for some time. Finally, motivated behavior leads to a goal. Whatever the definition, motivation is something that directs a person's behavior to achieve certain goals, which makes a person study hard (if he is a student), or work hard (if he is a worker), which can be measured by examining his behavior, and which can be influenced by many factors.

In relation to academic activities, Woolfolk revealed four motivational factors; namely desire, purpose, need and belief. Desire (arousal) is psychological reaction that cause students to be attracted to an activity (Shaughnessy, 2004). The goal is something to be achieved from the activities carried out. In the teaching and learning process, there are two types of goals, namely appearance and learning. Performance goal is a goal that looks good or can stand out in front of others. Learning goal are goals for developing abilities, 
even though they encounter many difficulties or challenges to display them. If someone has a performance goal, he tends to avoid risks and challenges and give up when he fails. But if someone has a learning goal, he tends to look for challenges and persevere when he encounters difficulties.

Needs can be defined as biological and psychological requirements that motivate someone to involve in an activity to achieve a goal (Taormina \& Gao, 2013). Maslow identified two types of needs, namely deficiency needs and growth needs. These two needs are known as the hierarchy of needs. Deficiency needs are the basic needs for physical and psychological well-being. These needs include the physiological needs of the need for security, the need for ownership and love, and the need for security, the need for belonging and love, and the need for respect or respect. Growth needs are further needs after basic needs are met. These needs include the need for curiosity and understanding, the need for beauty, and the need for self-actualization. Deficiency needs must be fulfilled before growth needs affect motivation.

In addition to desires, goals, and needs, belief in abilities is also a factor influencing motivation in learning (Li, 2014). When students believe that their abilities are sufficient (fixed), they tend to lead to performance goals and try to avoid failure. When they believe that abilities can be improved (improvable), they tend to lead to learning goals and can overcome their failures. In relation to learning English, there are several motivational factors (Bernaus \& Gardner, 2008), namely intrinsic goal toward English, extrinsic goal towards English, expectation of success, attitude towards people Americans and British people and their culture, anxiety, and strength (Robertson \& Nunn, 2010).

There are many opinions that reveal about the types of motivation. In general, theorists divide motivation into two types: intrinsic and extrinsic (Reiss, 2012). According to Reiss, intrinsic motivation is motivation where a person engages in an activity because it is driven by factors from within himself, for example for his pleasure, not to get rewards, and extrinsic motivation is motivation where someone engages in an activity because it is driven by factors outside of himself, for example to get an award. When a student is intrinsically 
motivated to learn, he does not need prizes or awards or punishment to make him study, because this activity itself is an award for him. Conversely, when a student is extrinsically motivated to learn, he does so with the aim of getting a prize or award, avoiding punishment, or pleasing the teacher.

In terms of achieving language skills, Gardner (Allen, Gardner, \& Lambert, 1974) divides motivation into integrative motivation and instrumental motivation. Integrative motivation is the desire to learn a language because someone wants to enter the culture of the language he is learning. Instrumental motivation is the desire to learn a language in order to get a better job or because the language to be studied is a requirement.

\section{METHODE}

\section{Research Problems}

a. What do the Supervising Teachers comment on the students' performances of English during teaching practicum?

b. What do Supervising Teachers suggest to increase the students motivation and confidence in using English as medium of instruction during teaching practice?

\section{Research Methods}

This study was conducted using qualitative approach. The data were collected through interviews.

\section{Population and Sample}

The population of this study is all teachers of English in senior High Schools who become supervising teachers for PST of Tarbiyah Faculty of IAIN Syaikh Abdurrahman Siddik Bangka Belitung. And here are the samples of this research:
a. Supervising Teacher of English from SMA Negeri 3 Pangkalpinang
b. Supervising Teacher of English from SMK Negeri 5 Pangkalpinang
c. Supervising Teacher of English from SMA Negeri 1 Puding Besar
d. Supervising Teacher of English from SMA Negeri 1 Mendo Barat, Bangka
e. Supervising Teacher of English from MAN I Pangkalpinang
f. Supervising Teacher of English from SMK Negeri 3 Pangkalpinang 
g. Supervising Teacher of English from MA Al Islam Kemuja, Bangka

\section{Findings and Discussion}

\section{Findings}

Interview with Teacher of English from MAN 1 Pangkalpinang, Mr. Ichksan, S.Pd.Ing

A. What do the Supervising Teachers comment on the students' performances of English during teaching practicum?

Some PSTs are lack of public speaking skill. They cannot control the big class. And most of all, their communication skill should be developed. Their motivation and confidence are low since they are not capable enough in doing classroom instruction using English. As a teacher of English they should use full English instruction when teaching. However, they are reluctant to do it. And it might because their low ability in English. But some PSTs are good already; they can handle the class very well. They are highly motivated and confident enough. Their speaking skill has been very excellent. It might because they have already taught in some English courses.

B. What do supervising teachers suggests in increasing the students' motivation and confidence in using English as medium of instruction during teaching practice?

PST can join English club where they have partners in their age to practice their English. The member of this club can be from all majors, as long as they have one thing in common; they want to develop their speaking skill in English. Moreover, as they study in Tarbiyah, as teachers' candidates, they also have do improve their classroom management. This classroom management are usually taught by lecturers in TEFL (Teaching English for Foreign Language) subject. Later on, after having the theories about classroom management, they will apply it in their peer teaching as well as microteaching. But once again, 
to sum up, they must practice again and again either in managing the classroom or doing instructions using good English.

Interview with Teacher of English from SMA Negeri 3 Pangkalpinag, Ibu Siti Napsiati, M.Pd.

A. What do the Supervising Teachers comment on the students' performances of English during teaching practicum?

As teachers candidate they did very well. I understand why they do not use $100 \%$ English in the class. They know that the students here have heterogeneous ability in comprehending English. The PSTs' motivation and confidence are not bad at all. They involved in activities in our school and they are highly dedicated. They often consult their problems in teaching to their supervising teachers, and this is good, showing that they are fully prepared before teaching. With a frequent practice, their teaching English will be much better and since they are in the process of learning how to be a good teacher, making mistakes is okay. As their supervising teachers, I am optimistic that they will be good teachers someday.

B. What do supervising teachers suggests in increasing the students' motivation and confidence in using English as medium of instruction during teaching practice?

PST students study and practice more on teaching strategies, methods, and approaches in language learning. They have to use authentic materials frequently, teaching media which support the learning process. For pre-service English teachers, collaborative teaching is also suggested and useful since they experience in teaching is not much, so team work can be one of the solution in creating a good learning atmosphere and smooth teaching.

Interview with Teacher of English from SMK Negeri 5 Pangkalpinang, Dwi Robani, S.Pd. 
A. What do the Supervising Teachers comment on the students' performances of English during teaching practicum?

TBI students who ever did their practicum teaching here have different knowledge and ability in teaching. They are all good in English, but their personality traits limit their learning instructions. Let's say that he is cheerful, he could create a comfortable learning atmosphere, but for those who are a bit silent, it's not easy for them to manage the classroom. And the situation became worse they did not use media in learning.

B. What do supervising teachers suggests in increasing the students' motivation and confidence in using English as medium of instruction during teaching practice?

To sum up, as teachers' candidate, they should develop their speaking skill and ability. They have to add their vocabulary knowledge by reading a lot and not lazy to look up the dictionary when they do not know the meaning words. By having good English, their confidence to speak English in front of classroom will increase. Second, they have to learn more about teaching methods, and strategies. Next, they should be creative and active in teaching and designing the lessons plans. Last but not least, PST students have to use media when teaching. So the students' focus not only in teachers' explanation but also in the media given.

Interview with Teacher of English from SMA Negeri 1 Puding Besar, Ibu Yusmaini, S.Pd.

A. What do the Supervising Teachers comment on the students' performances of English during teaching practicum?

PSTs that did their teaching practicum in SMA N 1 Puding Besar usually have difficulties in designing the lesson plans using 2013 Curriculum. It's not surprising since they might not get theories about the lesson planning in their campus before. As supervising teachers, I do 
hope that 2013 curriculum is introduced to PSTs when they learn curriculum development or other similar subjects in campus. In addition, some of them are not fluent enough to use English while teaching, they were not confidence and motivated. As a result, their teaching was awful. Since they are new to this real world of teaching, it is understandable, but some changes in curriculum at campus can be done in order to prepare them to be more ready to face their students later. The key is well prepared.

B. What do supervising teachers suggests in increasing the students' motivation and confidence in using English as medium of instruction during teaching practice?

a. The students should practice speaking English more and more before they teach;

b. The students should speak more fluently as they are the role model for their students

c. Emphasize more on the vocabulary knowledge in teaching speaking, accuracy will follow next; grammar is important in speaking but the students should not make grammar as skill based objective when they design the lesson.

Interview with Teacher of English from SMA Negeri 1 Mendo Barat, Ibu Yuni Ferawaty, S.Pd.

A. What do the Supervising Teachers comment on the students' performances of English during teaching practicum?

It is very true that practice makes perfect. The pre-service teachers of English who conducted their teaching practicum in SMA N 1 Mendo Barat have average skills of English proficiency. Only few of them were good. Having good English is not enough; they have to equip themselves with pedagogic competence. Peer teaching is one of ways in developing the students' ability in doing instructions. They will be more confidence and highly motivated if their competencies in teaching and learning process are fulfilled. 
B. What do supervising teachers suggests in increasing the students' motivation and confidence in using English as medium of instruction during teaching practice.

PST should practice speaking often, and this is one of lecturer's responsibilities to create such a cozy learning atmosphere for speaking class. If PSTs have good ability in speaking, their confidence will be increased. Lecturers should find a right strategy to make them speak in English. In addition, since most of the students who conducted their teaching practicum here were lack of classroom management and speaking ability, the use of teaching media would be very helpful. Unfortunately the In-Focus is not available in every class in SMA N 1 Mendo Barat. Learning media could really help the low-ability PST in teaching.

Interview with Teacher of English from MA AL-Islam Kemuja, Bangka, Ibu Yohana, S.Pd.

A. What do the Supervising Teachers comment on the students' performances of English during teaching practicum?

As far as I can say, the pre-service teachers of English were not disappointing. They are confident, motivated, and well prepared in teaching. They often asked questions and consult the lesson plan with their supervising teachers. They love learning, and this is important. They are not reluctant to discuss their plans in teaching. And this is very good; they are still in the process of learning how to teach well. The theories they get in campus can be just implement here directly when they have teaching practicum. Their English competence, and classroom management good.

B. What do supervising teachers suggests in increasing the students' motivation and confidence in using English as medium of instruction during teaching practice. 
As the PSTs are in the process of learning how to teach well, they have to pay attention more on how to create a cozy and comfortable learning atmosphere. And not to mention, the affective filter must be low since the high affective filter will block the students' comprehension on learning. Lowering the affective filter can be done by showing videos, listening to songs, and games. Students love playing through learning, indeed.

\section{Conclusions}

1. Supervising teachers realized that pre-service teachers of English are still in the process of learning how to be good teachers. Although some of PSTs are good already in terms of language skills and classroom management, but many still need to develop their proficiency especially in speaking. Most of them also feel reluctant to meet, discuss and consult their problems dealing with their teaching practicum at school. Some of them are confident and highly motivated, some are still nervous when they are assigned to teach in big classes. But their flaws in teaching considers normal since they have no experience in teaching before. With a lot of practices, their teaching will be much better in the future.

2. To develop PSTs' motivation and confidence, supervising teachers suggest some ideas. The first, PSTs should use learning media or authentic materials to enhance their lesson plan. The authentic material should be adapted based on the learners' needs. That's why they need to consult their supervising teachers about this. The second, before having teaching practicum at school, PSTs must know how to design lesson plans based on the curriculum implemented at school. And the current curriculum applied is 2013 curriculum. PSTs must have knowledge in formulating learning objectives (basic competencies and standard competencies) based on the syllabus and text books used at school. Lesson planning is a must in order to keep their teaching in the right track. Next, classroom management is also important issue to cover. PSTs need more peer teaching and after their peer teaching, the lecturers have to give reflection, evaluation, and suggestion for 
the better teaching in the future. Last but not least, as English is not our mother tongue, it needs specific approaches, methods, techniques, and strategies to teach English as foreign language. And as teachers' candidate, their TEFL methodology must be good enough.

3. In the future, it is advised that the PSTs learn how to teach the four skills and some competencies of English respectively. They do not learn how to teach English in general but let's make it gradually in listing patterns. It can be started by assigned them how to teach the four skills; listening, speaking, reading and writing. For the TEFL methodology course in TBI, please insert these four different teaching and learning. It can be simplified as shown in this table below.

Table 1. Suggested Syllabus in teaching TEFL Methodology for PSTs of Tadris Bahasa Inggris of IAIN Syaikh Abdurrahman Siddik Bangka Belitung

\begin{tabular}{|l|l|l|}
\hline No & \multicolumn{1}{|c|}{ Subject } & \multicolumn{1}{|c|}{ Material } \\
\hline 1 & How to teach English & $\begin{array}{l}\text { Classroom Management, Teaching } \\
\text { Strategies, Lesson Planning, Testing } \\
\text { and Evaluation }\end{array}$ \\
\hline 2 & How to teach Listening & $\begin{array}{l}\text { Classroom Management, Teaching } \\
\text { Strategies, Lesson Planning, Testing } \\
\text { and Evaluation }\end{array}$ \\
\hline 3 & How to teach Speaking & $\begin{array}{l}\text { Classroom Management, Teaching } \\
\text { Strategies, Lesson Planning, Testing } \\
\text { and Evaluation }\end{array}$ \\
\hline 5 & How to teach Reading & $\begin{array}{l}\text { Classroom Management, Teaching } \\
\text { Strategies, Lesson Planning, Testing } \\
\text { and Evaluation }\end{array}$ \\
\hline 6 & How to teach Grammar & $\begin{array}{l}\text { Classroom Management, Teaching } \\
\text { Strategies, Lesson Planning, Testing } \\
\text { and Evaluation }\end{array}$ \\
\hline 7 & How to teach Pronunciation & $\begin{array}{l}\text { Classroom Management, Teaching } \\
\text { Strategies, Lesson Planning, Testing } \\
\text { and Evaluation }\end{array}$ \\
\hline 8 & How to Teach Vocabularies & $\begin{array}{l}\text { Classroom Management, Teaching } \\
\text { Strategies, Lesson Planning, Testing } \\
\text { and Evaluation }\end{array}$ \\
\hline
\end{tabular}


Vol. 2 No. 2 Desember 2019, hal 212 - 227

\begin{tabular}{|l|l|l|}
\hline 9 & Etc & Etc \\
\hline
\end{tabular}

Allen, E. D., Gardner, R. C., \& Lambert, W. E. (1974). Attitudes and Motivation in Second-Language Learning. Hispania. https://doi.org/10.2307/339475

Armutcu, N., \& Yaman, Ş. (2010). ELT pre-service teachers' teacher reflection through practicum. In Procedia - Social and Behavioral Sciences. https://doi.org/10.1016/j.sbspro.2010.07.009

Bernaus, M., \& Gardner, R. C. (2008). Teacher motivation strategies, student perceptions, student motivation, and English achievement. Modern Language Journal. https://doi.org/10.1111/j.1540-4781.2008.00753.x

Cohen, L. (2010). A Guide to Teaching Practice. A Guide to Teaching Practice. https://doi.org/10.4324/9780203848623

Fairbanks, C. M., Freedman, D., \& Kahn, C. (2000). The role of effective mentors in learning to teach. Journal of Teacher Education. https://doi.org/10.1177/002248710005100204

Fathurrahman, F., \& Farih, A. (2019). IMPLEMENTASI PRAKTIK PENGALAMAN LAPANGAN (PPL) MAHASISWA PROGRAM STUDI PENDIDIKAN BAHASA INGGRIS FKIP UNIVERSITAS ISLAM LAMONGAN. JURNAL REFORMA. https://doi.org/10.30736/rfma.v7i2.80

Gan, Z. (2013). Learning to teach english language in the practicum: What challenges do non-native ESL student teachers face? Australian Journal of Teacher Education. https://doi.org/10.14221/ajte.2013v38n3.3

Inbar, O., Donitsa-Schmidt, S., \& Shohamy, E. (2001). Students' motivation as a function of language learning: The teaching of Arabic in Israel. In Motivation and second language acquisition.

Kabilan, M. K. (2013). A phenomenological study of an international teaching practicum: Pre-service teachers' experiences of professional development. Teaching and Teacher Education. https://doi.org/10.1016/j.tate.2013.07.013

Li, Q. (2014). Differences in the motivation of Chinese learners of English in a foreign and second language context. System. https://doi.org/10.1016/j.system.2014.01.011

Reiss, S. (2012). Intrinsic and Extrinsic Motivation. Teaching of Psychology. https://doi.org/10.1177/0098628312437704

Richards, J. C. (2001). Curriculum development in language teaching. Ernst Klett Sprachen. 
Jurnal Ilmiah Sustainable

Vol. 2 No. 2 Desember 2019, hal 212 - 227

Robertson, P., \& Nunn, R. (2010). The Asian EFL Journal Quarterly June 2010. Asian EFL Journal.

Schmidt, R., Boraie, D., \& Kassabgy, O. (1996). Foreign Language Motivation: Internal Structure and External Connections. Language Learning Motivation: Pathways to the New Century.

Segerstrom, S. C., \& O'Connor, D. B. (2012). Stress, health and illness: Four challenges for the future. Psychology and Health. https://doi.org/10.1080/08870446.2012.659516

Shaughnessy, M. F. (2004). An interview with Anita Woolfolk: The educational psychology of teacher efficacy. Educational Psychology Review. https://doi.org/10.1023/B:EDPR.0000026711.15152.1f

Taormina, R. J., \& Gao, J. H. (2013). Maslow and the motivation hierarchy: Measuring satisfaction of the needs. American Journal of Psychology. https://doi.org/10.5406/amerjpsyc.126.2.0155 